\title{
Nesidioblastosis of the pancreas: definition of the syndrome and the management of the severe neonatal hyperinsulinaemic hypoglycaemia
}

\author{
A AYNSLEY-GREEN, J M POLAK, S R BLOOM, M H GOUGH, J KEELING, \\ S J H ASHCROFT, R C TURNER, AND J D BAUM
}

University Department of Paediatrics, John Radcliffe Hospital, Oxford; Department of Pathology, Department of Surgery, Department of the Regius Professor of Medicine, and University Department of Clinical Biochemistry, Radcliffe Infirmary, Oxford; Department of Histochemistry and Department of Medicine, Hammersmith Hospital, London

SUMMARY Three newborn infants are reported who developed severe non-ketotic hypoglycaemia (blood glucose $<1.1 \mathrm{mmol} / 1 ; 19.8 \mathrm{mg} / 100 \mathrm{ml}$ ) within 6 hours of birth. All had inappropriately raised plasma insulin concentrations for the level of glycaemia, and required high rates of glucose infusion ( $>15 \mathrm{mg}$ glucose $/ \mathrm{kg}$ per minute) to prevent symptoms of hypoglycaemia. Medical treatment (hydrocortisone, diazoxide, chlorothiazide, phenytoin, propranolol, and depot glucagon) was ineffective in preventing hypoglycaemia and all 3 infants were subjected to partial and then total pancreatectomy. The pathological features of nesidioblastosis are reported from quantitative immunohistochemical studies on the pancreata. These results together with those from metabolic and endocrine studies performed on the 3 infants during the investigation of the cause of the hypoglycaemia and during the perioperative and postoperative period are presented in detail in order to define a practical approach to the management of this difficult clinical problem in the neonate.

Hyperinsulinism is a rare cause of severe persistent hypoglycaemia during the neonatal period. Nevertheless it is a diagnosis of importance since the hypoglycaemia may be exceedingly difficult to control, and associated with it is a high incidence of brain damage and subsequent mental retardation. ${ }^{1}$ In order to define a practical approach to the diagnosis and treatment of persistent neonatal hyperinsulinism we report studies on 3 infants with severe hypoglycaemia due to pancreatic nesidioblastosis who required total pancreatectomy to control the hypoglycaemia.

\section{Clinical presentation of the infants}

The relevant presenting clinical data are shown in
Table 1. The pregnancy in each case had been normal, and none of the mothers had had glycosuria or rhesus incompatibility. The infants developed symptoms due to hypoglycaemia within the first 6 hours of birth. Case 1 was 'jittery' from birth, Case 2 was hypotonic and had difficulty in feeding, Case 3 presented as an averted death at age 6 hours. ${ }^{2}$ Each infant resembled an infant of a diabetic mother (Fig. 1).

\section{Methods}

Biochemical and endocrine assay methods. Blood samples were drawn initially from the infants through indwelling umbilical catheters. Immediately on withdrawing, blood $(0.5-1.0 \mathrm{ml})$ was added to

Table 1 Clinical data on infants with nesidioblastosis

\begin{tabular}{|c|c|c|c|c|c|c|}
\hline Case & Sex & $\begin{array}{l}\text { Birthweight } \\
(k g)\end{array}$ & $\begin{array}{l}\text { Gestation } \\
\text { (weeks) }\end{array}$ & $\begin{array}{l}\text { Age symptoms } \\
\text { noted }\end{array}$ & Symptoms & $\begin{array}{l}\text { Initial blood glucose } \\
\text { concentration (mmol/l) }\end{array}$ \\
\hline $\begin{array}{l}1 \\
2 \\
3\end{array}$ & $\begin{array}{l}\mathbf{M} \\
\mathbf{F} \\
\mathbf{M}\end{array}$ & $\begin{array}{l}4 \cdot 380 \\
3 \cdot 650 \\
3 \cdot 700\end{array}$ & $\begin{array}{l}40 \\
38 \\
40\end{array}$ & $\begin{array}{l}\text { At birth } \\
4 \text { hours } \\
6 \text { hours }\end{array}$ & $\begin{array}{l}\text { Jittery } \\
\text { Floppy, feeding difficulty } \\
\text { Collapse, averted cot death }\end{array}$ & $\begin{array}{l}0 \cdot 55 \\
1 \cdot 1 \\
0 \cdot 5\end{array}$ \\
\hline
\end{tabular}

Conversion: SI to traditional units-glucose: $1 \mathrm{mmol} / 1 \approx 18 \mathrm{mg} / 100 \mathrm{ml}$. 


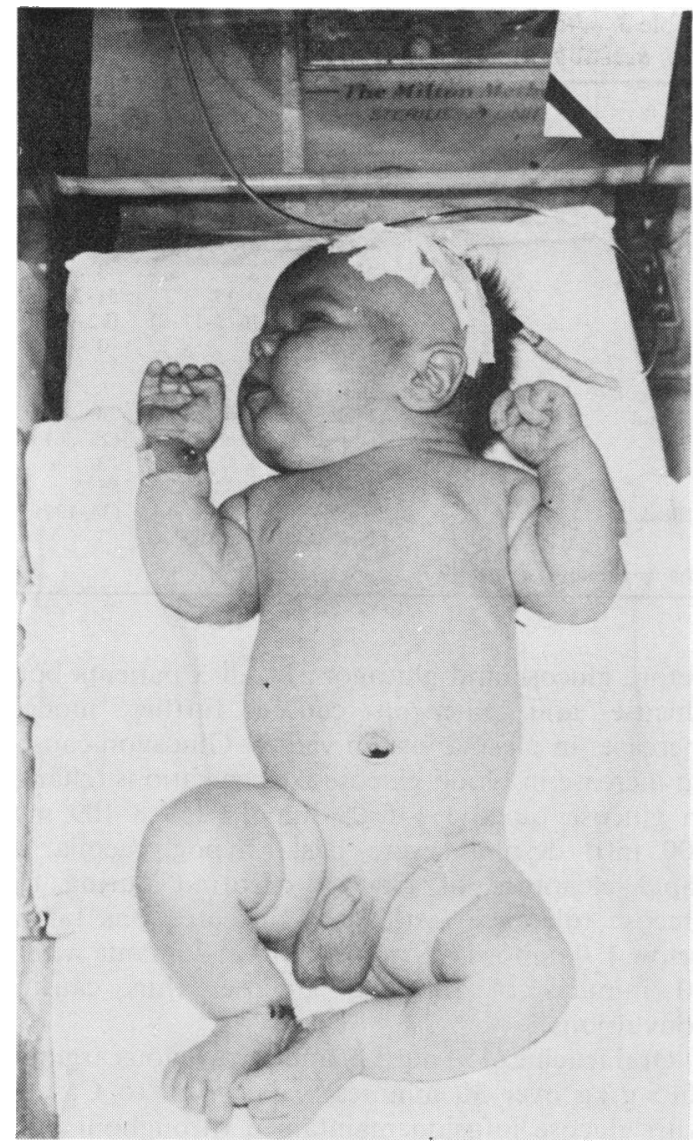

Fig. 1 (Case 1.) Clinical appearance at time of presentation showing generalised adiposity and resemblance to an infant of a diabetic mother.

$5 \mathrm{ml}$ ice-cold $10 \%$ perchloric acid for assay of intermediary metabolites. Blood $(0.5 \mathrm{ml})$ was also added to a heparinised tube for assay of plasma insulin and cortisol; $0.9 \mathrm{ml}$ was added to $0.1 \mathrm{ml}$ aprotonin (Trasylol) containing $50 \mathrm{mmol} / \mathrm{l}$ EDTA for assay of plasma glucagon. Plasma was stored at $-20^{\circ} \mathrm{C}$ until assayed. Levels of blood glucose, ${ }^{3}$ lactate, ${ }^{4}$ pyruvate, ${ }^{4}$ acetoacetate and $\beta$-hydroxybutyrate ${ }^{5}$ and alanine ${ }^{6}$ were determined by standard enzymatic techniques. Plasma insulin and glucagon were measured by radioimmunoassay. ${ }^{78}$

Histological and enzymatic studies. At laparotomy, fresh sections of resected pancreas were immediately quenched in Arcton (Freon) 12 at $-158^{\circ} \mathrm{C}$, freezedried overnight, fixed in benzoquinone vapour, ${ }^{9}$ and embedded in paraffin. Control pancreata, obtained at necropsy within 3-7 hours of death from 5 age- matched subjects dying from non-endocrine causes and without hypoglycaemia were prepared in a similar manner. Insulin, glucagon, somatostatin, and human pancreatic polypeptide cells were localised in serial sections by means of the peroxidase immunoperoxidase technique. ${ }^{10}$ Quantification of the proportions of A, B, D, and pancreatic polypeptide cells was carried out on a television image conversion analyser. ${ }^{11}$ Extracts of pancreatic tissue were prepared for radioimmunoassay of insulin, glucagon, and somatostatin. ${ }^{12}$ Sections of fresh formalin-fixed pancreas were also stained for insulin cells by the thiosulphation-aldehyde fuchsin technique. ${ }^{13}$

A liver biopsy taken at laparotomy from Case 1 was deep-frozen immediately in liquid nitrogen and kept at $-20^{\circ}$ until assays of hepatic enzymes could be performed. At the moment of biopsy the infant had a blood glucose concentration of $6.0 \mathrm{mmol} / \mathrm{l}$ $(108 \mathrm{mg} / 100 \mathrm{ml})$ with a $10 \%$ glucose infusion running at the rate of $20 \mathrm{mg}$ glucose $/ \mathrm{kg}$ per minute. Control liver samples were obtained from donors of organ transplants. The tissues were thawed and analysed for glycogen, ${ }^{14}$ protein, ${ }^{15} \alpha$-glucosidase, ${ }^{14}$ glucose-6-phosphatase, ${ }^{14}$ glycogen phosphorylase, ${ }^{14}$ and glycogen synthetase. ${ }^{16}$ Glycogen structure was shown by measuring maximum absorbance of the polysaccharide-iodine complex using twin cuvettes. ${ }^{17}$

Studies on insulin secretion from isolated islets of Langerhans in vitro. Pieces of fresh pancreas were immersed in oxygenated Krebs-Henseleit buffer and isolated islets of Langerhans extracted after incubation with collagenase as described previously. ${ }^{18}$ Rates of insulin release and biosynthesis, and islet content of adenosine triphosphate (ATP) were measured as follows.

\section{Insulin release and ATP content}

Batches of 3 islets were incubated in $0.3 \mathrm{ml} \mathrm{Krebs}$ bicarbonate medium containing albumin $(2 \mathrm{mg} / \mathrm{ml})$ and glucose $(0.4$ or $20 \mathrm{mmol} / \mathrm{l})$ for 2 hours at $37^{\circ} \mathrm{C}$. After incubation $0.2 \mathrm{ml}$ medium was separated from islets by sedimentation and the insulin concentration determined by radioimmunoassay using a charcoal method. ${ }^{19} 0.05 \mathrm{ml}$ ice-cold $10 \%$ perchloric acid was added to the remaining $0 \cdot 1 \mathrm{ml}$ of medium containing the islets. The islets were disrupted by sonication and ATP concentration in aliquots of the sonicate was measured using a luciferase assay as described previously. ${ }^{20}$

\section{Insulin and total protein biosynthesis}

Batches of islets were incubated at $37^{\circ} \mathrm{C}$ for 90 minutes in $0.1 \mathrm{ml}$ Krebs bicarbonate medium containing $4 \mu \mathrm{Ci}\left(4,5-{ }^{3} \mathrm{H}\right)$ leucine $\left(53 \mu \mathrm{Ci}^{5} \mu \mathrm{mol}\right)$, and glucose $(0.4$ or $20 \mathrm{mmol} / \mathrm{l})$. The incorporation 
of $\left({ }^{3} \mathrm{H}\right)$ leucine into insulin plus proinsulin was measured using insulin-binding affinity columns, and into total islet protein using trichloracetic acid precipitation as described previously in detail. ${ }^{21}$

\section{Results}

Initial investigations. Each infant had 2 blood samples drawn (one had 3) at about the time of presentation when hypoglycaemic. The results of the assays for plasma insulin and blood metabolites (Table 2) are compared with data from control infants of the same age. ${ }^{22}$

The mean blood glucose value was $0.91 \mathrm{mmol} / \mathrm{l}$ $(16.4 \mathrm{mg} / 100 \mathrm{ml})$ compared with $3.67 \mathrm{mmol} / \mathrm{l}$ $(66 \mathrm{mg} / 100 \mathrm{ml})$ in the controls $(P<0.01)$; mean plasma insulin level was considerably increased $(28.7$ v $6.8 \mu \mathrm{U} / \mathrm{ml}, \mathrm{P}<0.01)$. Associated with the inappropriately raised plasma insulin values were significantly lower concentrations of blood $\beta$ hydroxybutyrate $(0.030 \times 0.122 \mathrm{mmol} / \mathrm{l}, \mathrm{P}<0.01)$ and thus total blood ketone bodies ( $\beta$-hydroxybutyrate and acetoacetate). The mean concentrations of blood lactate and alanine were not appreciably different. The mean plasma glucagon concentration in Case 1 on day 1 when he was hypoglycaemic was $15.5 \mathrm{pmol} / \mathrm{l}(\mathrm{n}=3$, range $1 \cdot 5-24 \cdot 0)$, considerably lower than the mean value of $65 \cdot 2 \pm 11.7 \mathrm{pmol} / \mathrm{l}$ in the controls. Mean initial plasma cortisol concentration in the 3 infants was $800 \mathrm{nmol} / \mathrm{l}(29 \mu \mathrm{g} /$ $100 \mathrm{ml}$ ), indicating a substantial response to hypoglycaemia.

The infants were given an intravenous glucose tolerance test $(0.5 \mathrm{~g}$ glucose $/ \mathrm{kg})$ and a glucagon provocation test $(0.1 \mathrm{mg} / \mathrm{kg}$ intramuscularly). One infant received glucagon twice. The mean basal and peak blood glucose and plasma insulin values for the two tests are shown in Table 3. There was an inappropriate increase in plasma insulin for the low blood glucose concentrations in the basal samples

Table 2 Mean basal concentrations of plasma insulin and blood metabolites in 3 infants with nesidioblastosis $( \pm S E M)$

\begin{tabular}{|c|c|c|c|c|c|}
\hline & $\begin{array}{l}\text { Plasma } \\
\text { insulin } \\
(\mu U / m l)\end{array}$ & $\begin{array}{l}\text { Glucose } \\
\text { (mmol/l) }\end{array}$ & $\begin{array}{l}\text { Blood } \\
\text { ketones } \\
(\mathrm{mmol} / \mathrm{l})\end{array}$ & $\begin{array}{l}\text { Lactate } \\
(\mathrm{mmol} / \mathrm{l})\end{array}$ & $\begin{array}{l}\text { Alanine } \\
(\mathrm{mmol} / \mathrm{l})\end{array}$ \\
\hline $\begin{array}{l}\text { Mean } \\
\text { Number* }\end{array}$ & $\begin{array}{l}28 \cdot 7 \\
( \pm 3 \cdot 29)\end{array}$ & $\begin{array}{l}0.91 \\
( \pm 0.21)\end{array}$ & $\begin{array}{l}0.14 \\
( \pm 0.03)\end{array}$ & $\begin{array}{c}1 \cdot 87 \\
( \pm 0 \cdot 36)\end{array}$ & $\begin{array}{l}0.22 \\
( \pm 0.05) \\
5\end{array}$ \\
\hline $\begin{array}{l}\text { Control in } \\
\text { Mean } \\
\text { Number }\end{array}$ & $\begin{array}{c}\text { ants aged } 4 \\
6 \cdot 8 \\
( \pm 1 \cdot 3) \\
12\end{array}$ & $\begin{array}{c}6 \text { hours } \dagger \\
3 \cdot 67 \\
( \pm 0 \cdot 22) \\
12\end{array}$ & $\begin{array}{l}0.254 \\
( \pm 0.040) \\
12\end{array}$ & $\begin{array}{l}2 \cdot 37 \\
( \pm 0.71) \\
12\end{array}$ & $\begin{array}{l}0 \cdot 37 \\
( \pm 0 \cdot 10) \\
12\end{array}$ \\
\hline
\end{tabular}

* Two infants contributed two blood samples each, the third contributed three samples.

†Aynsley-Green et al.22
Table 3 Response to glucose and glucagon in infants with nesidioblastosis

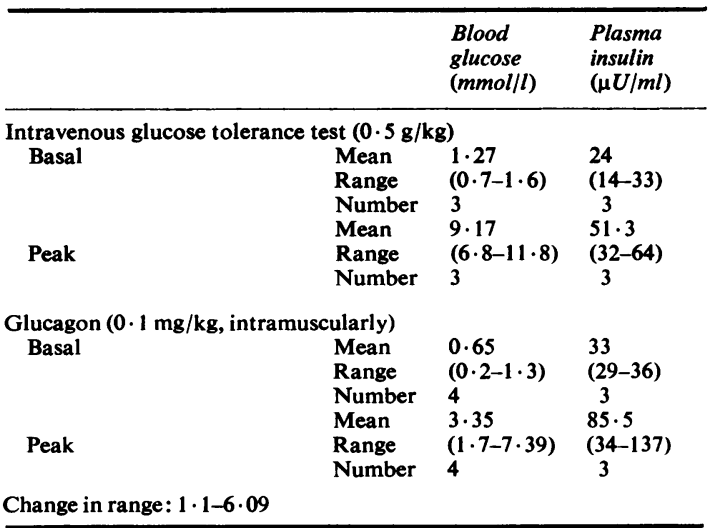

before glucose and glucagon. In all 3 patients both glucose and glucagon caused further modest increases in plasma insulin values. Glucagon caused an increase in blood glucose concentrations (change in glucose range $1 \cdot 1-6.09 \mathrm{mmol} / 1(19 \cdot 8-109 \mathrm{mg} /$ $100 \mathrm{ml})$ ) despite severe basal hypoglycaemia. A rapid clearance of glucose occurred during the glucose tolerance test, with concentrations falling below $1.0 \mathrm{mmol} / \mathrm{l}(18 \mathrm{mg} / 100 \mathrm{ml})$ in 2 infants within 30 minutes of injecting glucose, thus causing convulsions.

Oral leucine $(150 \mathrm{mg} / \mathrm{kg})$ and intravenous arginine $(0.5 \mathrm{~g} / \mathrm{kg}$ over 30 minutes) were given to Case 1 , with glucose infusion maintained throughout both tests at a constant rate of $15 \mathrm{mg} / \mathrm{kg}$ per minute. Despite this, the blood glucose concentration fell from $2.9 \mathrm{mmol} / 1(52 \mathrm{mg} / 100 \mathrm{ml})$ to $1.9 \mathrm{mmol} / 1$ $(34 \mathrm{mg} / 100 \mathrm{ml}) 60$ minutes after giving leucine, with an increase of plasma insulin from 25 to $31 \mu \mathrm{U} / \mathrm{ml}$. Arginine caused an increase in plasma insulin from 20 to $55 \mu \mathrm{U} / \mathrm{ml}$ within 20 minutes of the end of the infusion, with a fall in blood glucose from 2.5 to $1 \cdot 1 \mathrm{mmol} / \mathrm{l}(45$ to $19 \cdot 8 \mathrm{mg} / 100 \mathrm{ml})$.

Response to initial medical treatment. Immediate correction of the presenting hypoglycaemia was attempted by giving a bolus of glucose $(0.5 \mathrm{~g} / \mathrm{kg}$ intravenously) followed by a continuous glucose infusion. In all 3 infants hypoglycaemia with convulsions recurred during the first 24 hours despite glucose infusions (mean rate $6 \mathrm{mg} / \mathrm{kg}$ per minute) and before the magnitude of the glucose requirement was appreciated fully. The rate of glucose infusion was increased rapidly to 15,17 , and $25 \mathrm{mg} / \mathrm{kg}$ per minute respectively (Table 4) but despite these high infusion rates it was not possible to restore normoglycaemia although the infants no longer had symptoms. 
Table 4 Response of blood glucose to initial medical treatment

\begin{tabular}{|c|c|c|c|}
\hline Case & $\begin{array}{l}\text { Glucose infusion } \\
\text { alone }(\text { mmol } / l) \\
\text { (mean } \pm S E M)\end{array}$ & $\begin{array}{l}\text { Rate } \\
(\mathrm{mg} / \mathrm{kg} \text { per } \mathrm{min})\end{array}$ & $\begin{array}{l}\text { Glucose + diazoxide } \\
(20 \mathrm{mg} / \mathrm{kg} \text { per day })+ \\
\text { hydrocortisone } \\
(10 \mathrm{mg} / \mathrm{kg} \text { per day })\end{array}$ \\
\hline $1(n=6)$ & $1 \cdot 57 \pm 0 \cdot 23$ & 15 & $\begin{array}{l}1.95 \pm 0.23 \\
n=21\end{array}$ \\
\hline $2(n=5)$ & $0.72 \pm 0.27$ & 17 & $\begin{array}{l}7 \cdot 11 \pm 0.52 \\
n=9\end{array}$ \\
\hline $3(n=7)$ & $1.09 \pm 0.27$ & 25 & $\begin{array}{l}3.43 \pm 0.33 \\
n=24\end{array}$ \\
\hline
\end{tabular}

Hydrocortisone $5 \mathrm{mg} / \mathrm{kg} 12$ hourly intramuscularly was begun empirically, but this did not affect blood glucose concentrations (mean blood glucose before hydrocortisone $1.09 \pm 0.7 \times 1.70 \pm 0.67 \mathrm{mmol} / 1$ during treatment with hydrocortisone). Having demonstrated hyperinsulinism, diazoxide $20 \mathrm{mg} / \mathrm{kg}$ per day given at 8-hourly intervals was then introduced, with maintenance of the same rate of glucose infusion and the same dose of hydrocortisone. Mean blood glucose concentrations after the addition of diazoxide to the glucose infusion treatment are shown in Table 4; a beneficial effect was seen in Cases 2 and 3, with increases of blood glucose to means of $7 \cdot 11 \mathrm{mmol} / 1(128 \mathrm{mg} / 100 \mathrm{ml})$ and 3.43 $\mathrm{mmol} / \mathrm{l}(62 \mathrm{mg} / 100 \mathrm{ml})$ respectively. In only Case 2 however, was it possible to stop the glucose infusion; the other 2 infants remained glucose drip-dependent despite adding chlorothiazide $125 \mathrm{mg} /$ day and because of this they were submitted to laparotomy at 17 and 12 days of age respectively. Progressive enlargement of the liver was noted in all infants during the first week. All the infants were given glucagon injections to prevent severe hypoglycaemia during the resiting of glucose infusions.

Case 2 was maintained on a daily dose of diazoxide $20 \mathrm{mg} / \mathrm{kg}$ per day, but then developed sporadic hypoglycaemic episodes for no apparent cause with blood glucose concentrations less than $1.0 \mathrm{mmol} / \mathrm{l}$. Two attempts to discharge the infant resulted in emergency readmissions with hypoglycaemic convulsions. Laparotomy was performed at age 14 weeks.

Studies at the time of the first laparotomy. In all 3 patients a $10 \%$ dextrose infusion was maintained throughout surgery, with anaesthesia maintained by halothane, nitrous oxide, and air. Macroscopical examination of the pancreas was normal without evidence for a localised pancreatic adenoma. A subtotal resection $(75 \%)$ of the pancreas was performed in each case.

Blood glucose concentrations increased in all 3 infants during the operation before resection of the pancreas (mean value 60 minutes after induction of anaesthesia being $10.0 \mathrm{mmol} / \mathrm{l} ; 180 \mathrm{mg} / 100 \mathrm{ml}$ ). Portal vein blood samples drawn immediately before resection of the pancreas had a mean plasma insulin concentration of $87 \mu \mathrm{U} / \mathrm{ml}$ which fell in 2 infants to a mean value of $18 \mu \mathrm{U} / \mathrm{ml}$ after subtotal resection. Blood glucose values on return from the theatre were $16 \cdot 6,15 \cdot 6$, and $7 \cdot 5 \mathrm{mmol} / \mathrm{l}(299,281$, and $135 \mathrm{mg} / 100 \mathrm{ml}$ ) respectively. None of the infants remained hyperglycaemic after the first 24 hours after surgery, and all again required glucose infusions to prevent hypoglycaemia.

\section{Case 1}

The subsequent course of Case 1 requires further comment, since experience with his management determined our treatment of the two others. During the first postoperative days, blood glucose concentrations were maintained initially on a glucose infusion and then on feeds at 2- to 3-hourly intervals. Recurrent hypoglycaemia (mean blood glucose $2.0 \mathrm{mmol} / 1(36 \mathrm{mg} / 100 \mathrm{ml})$, mean plasma insulin $6 \mu \mathrm{U} / \mathrm{ml}$ ) led to the reintroduction of diazoxide (20 mg/kg per day) and chlorothiazide $(125 \mathrm{mg}$ daily) without appreciable improvement. Addition of zinc protamine glucagon $(0.5 \mathrm{mg}$ intramuscularly 12 hourly) had an initial beneficial effect, but after 4 weeks of treatment recurrent hypoglycaemia again developed. Introduction of phenytoin ${ }^{23} 24$ and propranolol $^{25}$ did not improve blood glucose concentrations. A $95 \%$ pancreatectomy was performed at age 3 months (see below). The pancreatic remnant from the previous operation appeared to have regenerated to the size of the original pancreas. Postoperatively, blood glucose concentrations remained initially between 3.5 and $6.0 \mathrm{mmol} / \mathrm{l}$ (63 and $108 \mathrm{mg} / 100 \mathrm{ml}$ ), but fell progressively to $1.9 \mathrm{mmol} / \mathrm{l}(34 \mathrm{mg} / 100 \mathrm{ml})$, associated with a convulsion. Reintroduction of diazoxide and chlorothiazide did not improve the situation. An attempt was made to increase blood ketone body concentrations as alternative fuels to glucose by giving a diet rich in medium chain triglycerides ${ }^{26}$ and then by giving growth hormone $(2 \mathrm{mg}$ daily intramuscularly). ${ }^{27}$ No appreciable increase in blood ketone body concentrations occurred with either treatment, nor was there any change in symptoms of neuroglycopenia. Reintroduction of zinc protamine glucagon ( $0.5 \mathrm{mg}$ intramuscularly 12 hourly) had a transient beneficial effect, but recurrent hypoglycaemic episodes persisted. A total pancreatectomy was performed at age 6 months which caused persistent hyperglycaemia requiring treatment with insulin.

Following this experience, and having demonstrated persistent hypoglycaemia despite diazoxide after partial pancreatectomy in Cases 2 and 3 both 
were submitted to total pancreatectomy within 2 weeks of the first operation, inducing insulindependent diabetes.

Histological studies. In Cases 1 and 3 sections of the pancreas prepared by the thiosulphation-aldehydefuchsin technique could be recognised immediately as being abnormal, with widespread infiltration of the acinar tissue by both individual and groups of insulin-containing cells (Fig. 2). Sections prepared with this technique from the pancreas of Case 2 could have been considered normal. However, the results of the immunohistochemical studies confirmed the diagnosis of nesidioblastosis in each case (Fig. 3), with individual and groups of endocrine cells secreting insulin, glucagon, somatostatin, and

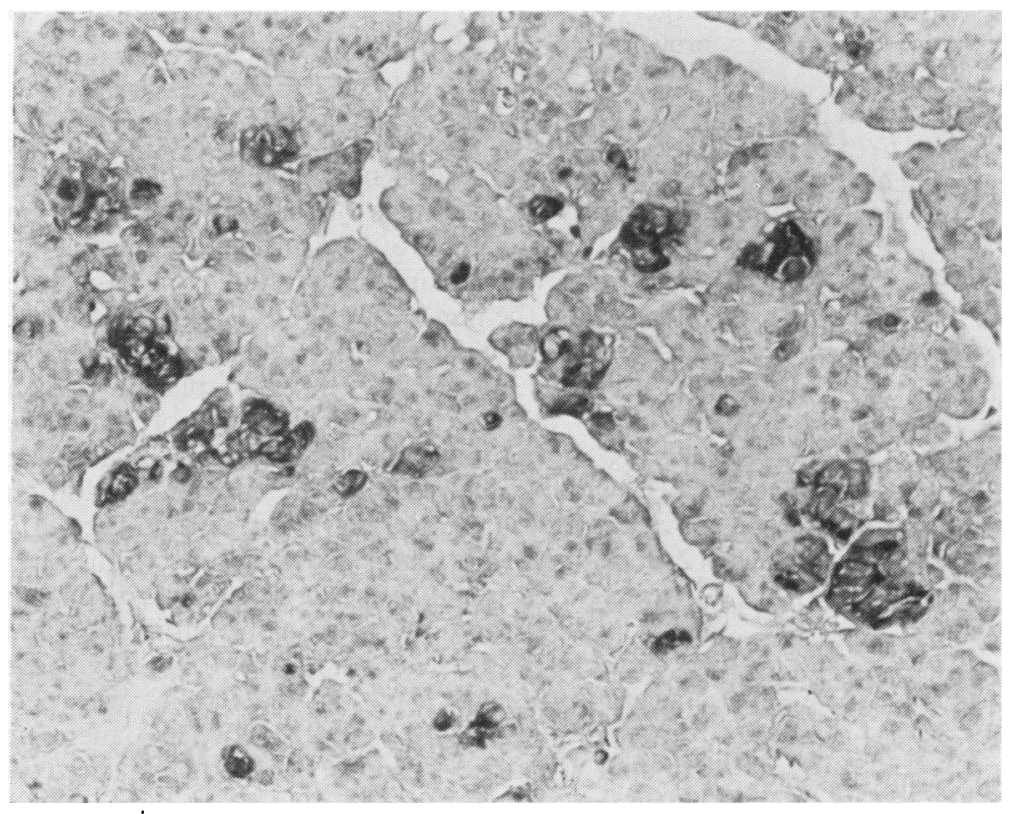

Fig. 2 (Case 1.) Section of pancreas prepared by the sulphation-aldehyde fuchsin technique showing large numbers of insulin-secreting cells present individually and in groups. $\times 200$.

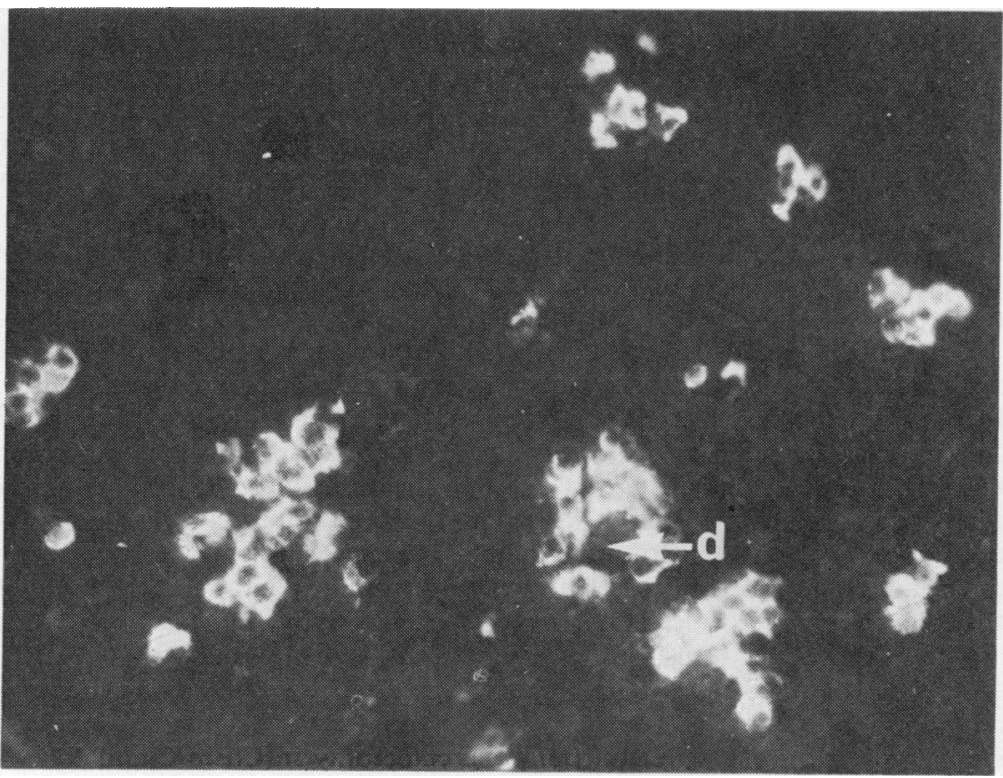

Fig. 3 (Case 1.) Immunohistological preparation of pancreas showing numerous hyperplastic insulin cells in nesidioblastosis, some 'budding off' the ducts $(d) . \times 220$. 
pancreatic polypeptide lying in acinar tissue and duct epithelieum (Fig. 4). The results of quantitative analysis of pancreata from the controls and the patients are shown in Table 5 in two ways-namely, the percentage of background area occupied by all the endocrine cells, islets, and specific hormonesecreting cells, and the percentage of total endocrine area occupied by each endocrine cell type. In control
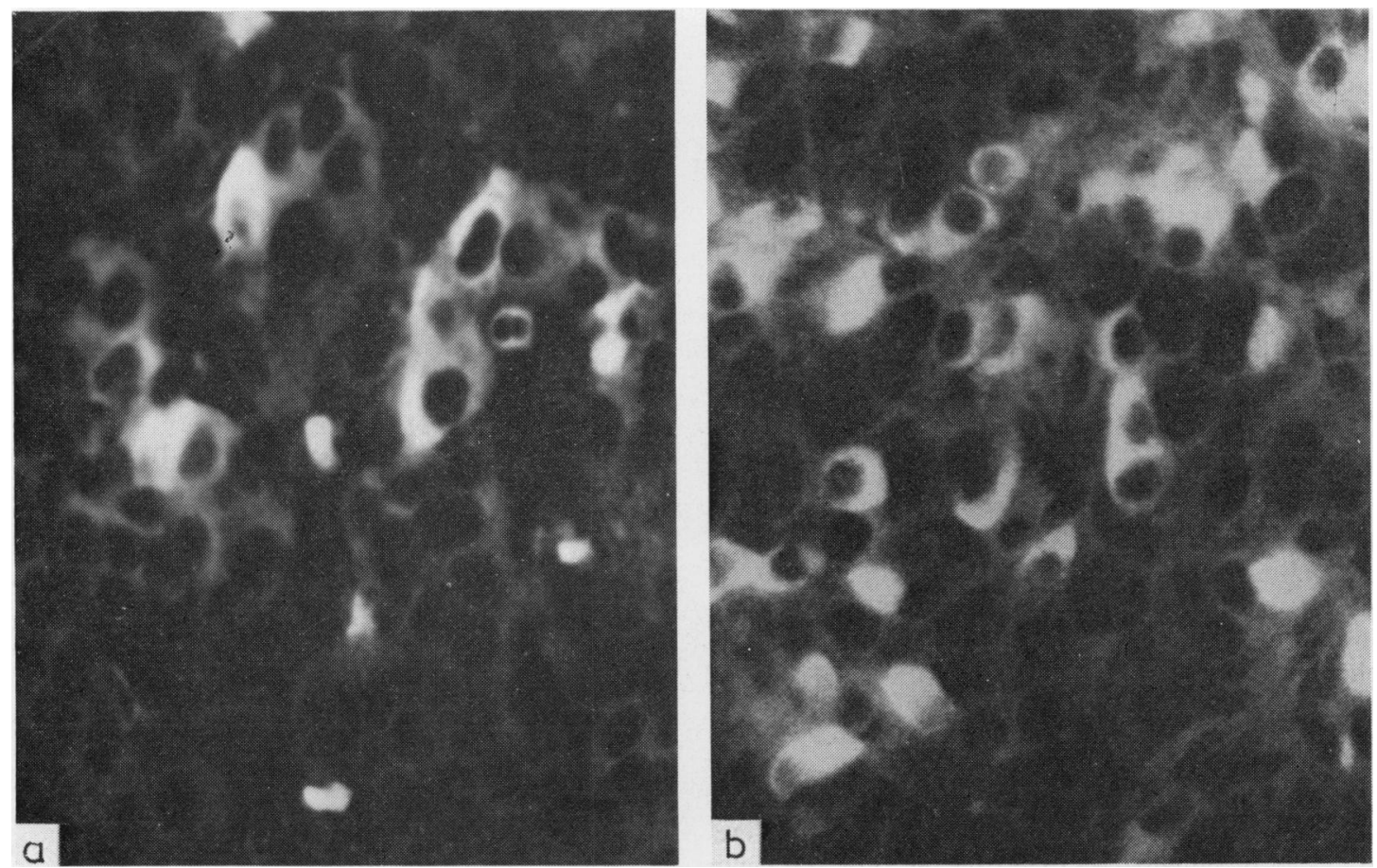

Fig. 4 Immunohistological preparation of pancreata showing somatostatin cells in (a) nesidioblastosis (Case 1) and (b) control. Note the remarkable reductions of the number and immunostaining of the somatostatin cells. $\times 700$.

Table 5 Analysis of immunohistochemical studies on pancreata from controls and patients. Results are expressed as $\%$ background area

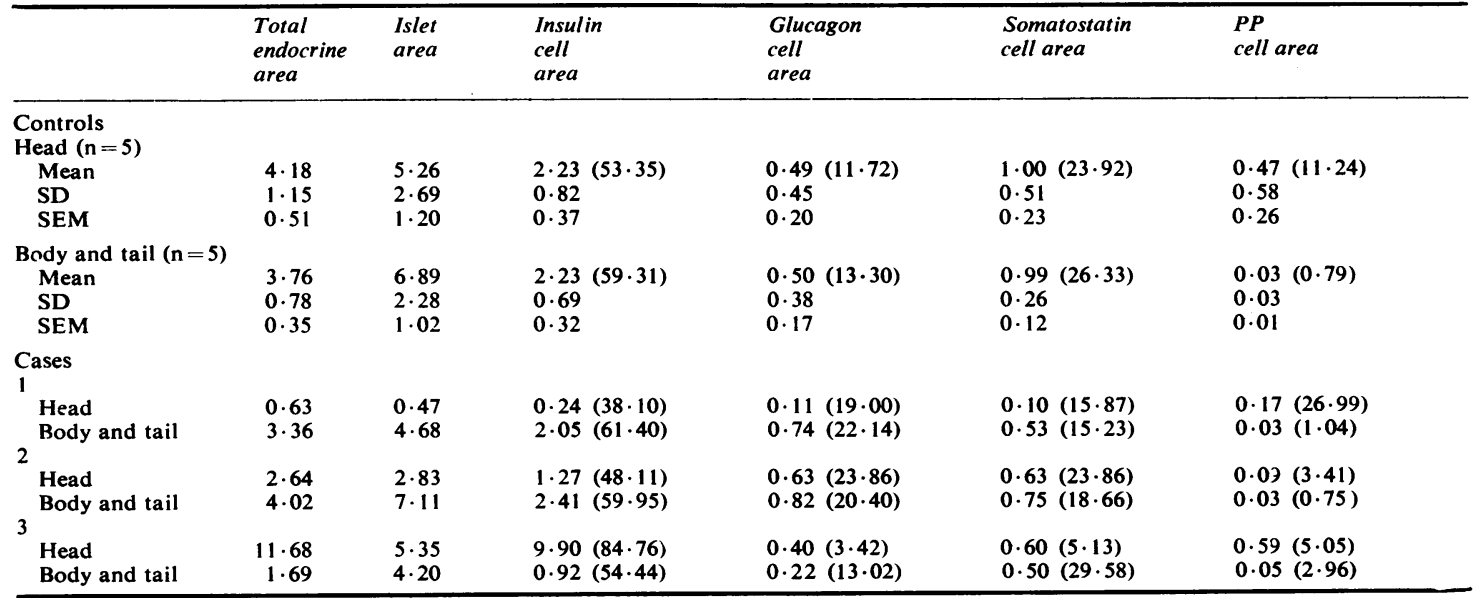

Figures in parentheses $=\%$ total endocrine area

$\mathbf{P P}=$ pancreatic polypeptide. 
pancreata the percentage total endocrine area and islet area are similar in the head of the pancreas and the body and tail, with similar percentages of cells secreting insulin, glucagon, and somatostatin. More polypeptide-secreting cells are present in the head of the pancreas. Compared with controls, the 3 patients showed pronounced differences both in the distribution of the endocrine cells in the various parts of the pancreas, and in the proportions of the cell types present. Thus in addition to a failure to form normal discrete islets of Langerhans, these pancreata show abnormal quantification of the individual cell types. In Case 3 a microadenoma composed mainly of $B$ cells was also found in the head of the pancreas.

Enzymatic studies on liver biopsy. Results of enzyme studies performed on the liver biopsied from Case 1 are shown in Table 6 . The glycogen content was increased $(12 \cdot 3 \mathrm{~g} / 100 \mathrm{~g}$ in patient, $1-6 \mathrm{~g} / 100 \mathrm{~g}$ in controls) but the structure was normal (change in maximum of iodine complex $465 \mathrm{~nm}$ : controls 460 ). The protein content was also normal $(181 \mathrm{mg} / \mathrm{g}$; control range 170-220) as were the activities of glycogen synthetase and glycogen phosphorylase. Interestingly, there was a greater activity of glycogen phosphorylase in the absence of cyclic AMP than in its presence, while the activity of debranching enzyme (amylo-1, 6-glucosidase) was lower.

In vitro studies on isolated islets of Langerhans. Sections of pancreata from all 3 patients were prepared by collagenase digestion but only the yield of islets from Case 1 was sufficient to perform incubation studies.

\section{Insulin release}

In the absence of glucose, the rate of insulin release was $17 \cdot 7 \pm 3 \cdot 2 \mu \mathrm{U} /$ islet per hour $(\mathrm{n}=4)$. The rate of release was increased in the presence of $4 \mathrm{mmol} / \mathrm{l}$ glucose $(39.5 \pm 6 \cdot 8 \mu \mathrm{U} /$ islet per hour, $\mathrm{n}=3)$ but no further increase was seen in the presence of $20 \mathrm{mmol} / \mathrm{l}$ glucose $(44.9 \pm 9.8 \mu \mathrm{U} /$ islet per hour, $\mathrm{n}=4)$.

Table 6 (Case 1). Enzymatic studies on liver biopsy

\begin{tabular}{|c|c|c|c|}
\hline & & Case 1 & Controls \\
\hline \multicolumn{2}{|c|}{$\begin{array}{l}\text { Glycogen }(g / 100 \mathrm{~g}) \\
\text { Iodine complex }(\lambda \text { max })(\mathrm{nm})\end{array}$} & $\begin{array}{l}12 \cdot 3 \\
465\end{array}$ & $\begin{array}{l}1-6 \\
\approx 460\end{array}$ \\
\hline \multirow{2}{*}{\multicolumn{2}{|c|}{$\begin{array}{l}\text { Protein }(\mathrm{mg} / \mathrm{g}) \\
\text { Glycogen synthetase c̀ G-6-P (U/g) }\end{array}$}} & 181 & $170-220$ \\
\hline & 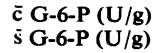 & $\begin{array}{l}2.51 \\
0.03\end{array}$ & $\begin{array}{l}1.99 ; 3.60 \\
0.02 ; 0.16\end{array}$ \\
\hline Phosphorylase & $\begin{array}{l}\bar{c} \operatorname{AMP}(U / g) \\
\bar{s} \operatorname{AMP}(U / g)\end{array}$ & $\begin{array}{l}18 \cdot 5 \\
20 \cdot 1\end{array}$ & $15-30$ \\
\hline \multirow{2}{*}{\multicolumn{2}{|c|}{$\begin{array}{l}\alpha \text {-Glucosidase }(U / g) \\
\text { Glucose-6-phosphatase }(U / g) \\
\text { Amylo-1, 6-glucosidase }(U / g)\end{array}$}} & $\begin{array}{r}0 \cdot 7 \\
4 \cdot 0\end{array}$ & $\begin{array}{l}0 \cdot 5-0 \cdot 7 \\
2-10\end{array}$ \\
\hline & & 106 & $\approx 200$ \\
\hline
\end{tabular}

Table 7 Measurements of pancreatic hormones in tissue extracts

\begin{tabular}{llll}
\hline Case & $\begin{array}{l}\text { Insulin } \\
(\mathrm{nmol} / \mathrm{g})\end{array}$ & $\begin{array}{l}\text { Glucagon } \\
(\mathrm{nmol} / \mathrm{g})\end{array}$ & $\begin{array}{l}\text { Somatostatin } \\
(\mathrm{pmol} / \mathrm{g})\end{array}$ \\
\hline 1 & 43 & $3 \cdot 0$ & 202 \\
2 & 28 & $5 \cdot 6$ & 73 \\
3 & 71 & $1 \cdot 9$ & 97 \\
$\begin{array}{l}\text { Controls } \\
\text { (n=4) }\end{array}$ & & & \\
(mean \pm SD) & $23 \pm 17$ & $4 \cdot 2 \pm 1 \cdot 4$ & $500 \pm 89$ \\
\hline
\end{tabular}

\section{ATP content}

The ATP content was $15 \cdot 1 \mathrm{pmol} /$ islet in the absence of glucose, $26 \cdot 1 \pm 8.9 \mathrm{pmol} /$ islet with $4 \mathrm{mmol} / \mathrm{l}$ glucose and $21.7 \mathrm{pmol} /$ islet in the presence of $20 \mathrm{mmol} / \mathrm{l}$ glucose $(\mathrm{n}=4)$.

\section{Insulin and protein biosynthesis}

Insulin plus proinsulin accounted for $9 \cdot 0 \pm 0.6 \%$ of total islet protein synthesis for islets incubated in the absence of glucose, $9.7 \pm 1.0 \%$ with $4 \mathrm{mmol} / 1$ glucose and $11 \cdot 1 \pm 1 \cdot 3 \%$ with $20 \mathrm{mmol} / 1$ glucose. Neither proinsulin plus insulin nor total protein synthesis rate was significantly higher with glucose $(4$ or $20 \mathrm{mmol} / \mathrm{l})$ than in its absence.

Radioimmunoassay of pancreatic tissue extracts. The results of assays of insulin, somatostatin, and glucagon in the pancreatic extracts from the 3 patients and the controls are shown in Table 7. The content of insulin was greatly increased in pancreata from Cases 1 and 3, the two infants with the most severe illness. The somatostatin content was greatly reduced in all 3 infants.

\section{Discussion}

Transient neonatal hypoglycaemia due to hyperinsulinism is seen commonly in infants of diabetic mothers, infants with erythroblastosis fetalis, and in those with the Wiedemann-Beckwith syndrome. Persistent hyperinsulinaemic hypoglycaemia is rarer in the neonate, although it assumes increasing importance during the first year of life to become the most common cause of severe hypoglycaemia in this age group. ${ }^{29}$ Several authors have stressed the high incidence of mental retardation in survivors which may be related to the delay in making the diagnosis and to the extreme difficulty experienced in controlling the hypoglycaemia. ${ }^{128-30} \mathrm{~A}$ confusing number of histological terms has been used to describe the anatomy of the pancreas in such cases.

Histology and pathophysiology. Nesidioblastosis, a term derived by Laidlaw in $1938,{ }^{31}$ indicates the 
formation of isolated endocrine cells and islets from pancreatic duct cells. Brown and Young ${ }^{32}$ first reported the association of nesidioblastosis with severe infantile hypoglycaemia, and Yakovac et al ${ }^{33}$ stressed that although conventional histological staining with haematoxylin and eosin showed unmistakable evidence for beta cell hypertrophy and islet hyperplasia in only a small number of pancreata removed from infants with severe hypoglycaemia, all showed nesidioblastosis when stained by insulinspecific methods. Heitz et al. ${ }^{34}$ reported that pancreata from such hyperinsulinaemic newborn infants had additional abnormalities in the distribution and number of glucagon, somatostatin, and pancreatic polypeptide cells. The disease is not therefore, restricted to insulin cells alone. Such analysis can only be obtained by using specific immunohistochemical methods to identify and quantify the individual hormone producing cell types. Heitz et al. also concluded that the various patterns of endocrine proliferation that had been previously recognised-such as isolated adenoma, hyperplasia, and microadenomatosis-were all variants of nesidioblastosis. This conclusion is supported by our observation of a discrete microadenoma existing with diffuse nesidioblastosis in the pancreas of Case 3.

Polak and Bloom ${ }^{12}$ stressed the importance of the increased insulin : somatostatin cell ratio as a diagnostic feature of nesidioblastosis. In their series of $\mathbf{8}$ cases, there was a change in the ratio from about 2 insulin: 1 somatostatin cell seen in the fetus and normal neonate to 5 insulin: 1 somatostatin cell. The normal close anatomical relationship of these two cell types was also lost. Their observation, also present in our 3 patients, that the somatostatin content of the pancreata was less than half that seen in controls substantiates the implication from morphometry that somatostatin 'deficiency' is a major feature of this disease.

There is no information on the metabolic and secretory activities of normal neonatal human pancreatic islets despite detailed knowledge of islet function in experimental animals. For this reason it is difficult to state whether the isolated islets used in the present study in vitro showed normal or abnormal behaviour. However one feature of the result is of note: insulin release from the isolated islets was stimulated maximally by $4 \mathrm{mmol} / \mathrm{l}$ glucose and no further increase in secretion rate was elicited by $20 \mathrm{mmol} / \mathrm{l}$ glucose. Moreover the rate of insulin biosynthesis was also little affected by the presence of added glucose, even though the viability of these islets was attested to by the ATP content which was similar to that of collagenase-isolated rodent islets. $^{20}{ }^{35}$ These findings are in contrast to those in rat islets in which insulin biosynthesis and release respond markedly to changes in glucose concentration over the range $4-20 \mathrm{mmol} / \mathrm{l}^{36} 37$ They also contrast with data obtained from islets from a 4-year-old girl with 'idiopathic' hypoglycaemia ${ }^{64}$ and from normal adult human islets maintained in tissue culture for one week $;^{38}$ in both these studies insulin release was stimulated by raising the glucose concentration from $3 \cdot 3$ to $16 \cdot 7 \mathrm{mmol} / 1$.

Thus the islets studied here show an abnormal sensitivity to glucose, with both biosynthesis and release being stimulated maximally by fairly low glucose concentrations, and this may contribute substantially to the hyperinsulinaemia.

Aetiology. The aetiology of the histological abnormality in nesidioblastosis is unknown. Heitz et al. ${ }^{\mathbf{3 4}}$ suggested that the histological resemblance of nesidioblastotic pancreata to those from immature fetuses had arisen as a result of inappropriate control during the earliest phases of endocrine pancreatic development. Whether this is due primarily to a genetic defect or as the result of external factors cannot be answered until more is known of the factors regulating fetal pancreatic development. That there may be a genetic component with an autosomal recessive inheritance pattern is suggested by the familial occurrence of neonatal nesidioblastosis ${ }^{39-41}$ and nesidioblastosis in familial endocrine adenomatosis. ${ }^{42}$ No factors common to the three mothers during pregnancies in terms of treatment with drugs or infections could be found in our series.

Leucine has been implicated as a stimulatory factor for B-cell neogenesis in nesidioblastosis. ${ }^{32}$ However it is difficult to envisage leucine as a major factor since all four endocrine cell types are affected. A systematic analysis of all hormones known to regulate pancreatic function may show the factor whose excess or lack is responsible for the uncontrolled expansion of islet cells. ${ }^{43}$

The natural history of the histological changes in neonatal nesidioblastosis is also unknown. The pancreas from Case 1 after the total resection at age 6 months had a histological appearance similar to that part resected at age 12 weeks. Of practical importance is the continuing regeneration of the pancreatic remnants left after the first two resections in this infant. Whether this represents normal regeneration of the gland or continued growth under the influence of abnormal stimulation is unknown.

Clinical presentation. All three patients presented during the first 6 hours of life. Two had classical symptoms of hypoglycaemia; the third infant presented as an averted neonatal death. He was 
severely hypoglycaemic when found collapsed in his cot, and without resuscitation he would have died. Polak and Wigglesworth ${ }^{44}$ reported an infant found inexplicably dead in her cot at age 80 hours who had extensive pancreatic nesidioblastosis. Thus hypoglycaemia due to pancreatic nesidioblastosis may be an important cause for unexpected death in the early neonatal period and we have suggested that insulin-specific staining methods should be used to examine the pancreata from all such cases. ${ }^{2}$ Whether hyperinsulinism can cause fatal hypoglycaemia in an older infant without any previous symptoms to suggest hypoglycaemia has yet to be proved, although Cox et al. ${ }^{45}$ reported that $36 \%$ of pancreata from infants with the sudden infant death syndrome had pancreatic endocrine abnormalities.

It is not known whether our infants had intrauterine hyperinsulinism. In favour of this are the facts that hyperinsulinism was demonstrated within hours of birth and that all three had a similar physical appearance, resembling that of an infant of a diabetic mother. None of the infants had hepatomegaly at birth, but all developed progressive liver enlargement during the first days.

Diagnosis of hyperinsulinism. Table 8 lists the important diagnostic points for hyperinsulinism. The most important is the demonstration of inappropriate plasma insulin values for the levels of glycaemia. Insulin release normally falls to very low levels when blood glucose concentrations decrease ${ }^{46}$ and the demonstration even of normal fasting levels of plasma insulin during severe hypoglycaemia implies a defect in the control of basal insulin release. The calculation of glucose infusion rate (in terms of $\mathrm{mg} / \mathrm{kg}$ per minute) required to maintain normoglycaemia is more useful than calculation of glucose disappearance rate from an intravenous glucose tolerance test in that it gives a direct indication of glucose need and allows changes in condition or response to treatment to be recognisable immediately. It also obviates the need to perform a glucose tolerance test which carries the danger of severe hypoglycaemia soon after the injection of glucose (since the maintainance infusion of glucose needs to be stopped for the test). Thus the glucose tolerance test is unnecessary if glucose infusion rates greater than $10 \mathrm{mg} / \mathrm{kg}$ per minute are required to maintain

\section{Table 8 Diagnostic points for hyperinsulinism}

(1) Inappropriately raised plasma insulin concentrations for blood glucose values

(2) Glucose infusion rate $>15 \mathrm{mg} / \mathrm{kg}$ per minute to maintain blood glucose level $>2 \mathrm{mmol} / 1$ (36 mg/100 ml)

(3) Low blood ketone bodies during hypoglycaemia

(4) Glycaemic response to glucagon despite hypoglycaemia normoglycaemia (the normal glucose production rate in the newborn infant is about $6 \mathrm{mg} / \mathrm{kg}$ per minute). ${ }^{47}$

The presence of low blood ketone body values support the diagnosis of hyperinsulinism since hypoglycaemia should normally induce the release of the counter-regulatory hormones glucagon, somatostatin, growth hormone, cortisol, and catecholamines, the end result being mobilisation of fat and generation of ketone bodies. Insulin prevents lipolysis so that the demonstration of non-ketotic hypoglycaemia strongly supports the diagnosis of hyperinsulinism. ${ }^{48}$ Our results show that this is true also for the newborn infant.

An increase in blood glucose after glucagon during hypoglycaemia also favours hyperinsulinism, since most other hypoglycaemic conditions in infancy induce a starvation-like state with exhaustion of liver glycogen and a failure to increase blood glucose after glucagon. In nesidioblastosis however, the excess insulin secretion directs glucose into inappropriate glycogen formation, explaining the development of hepatomegaly in all cases and the results of the liver biopsy in Case 1.

Hirsch et al. ${ }^{49}$ reported the striking and prolonged effect of infusions of somatostatin in an infant with nesidioblastosis (see below). Somatostatin was not available for trial in our infants, but it may prove to be a useful diagnostic test.

Neither the leucine provocation test nor the response to arginine infusion in Case 1 helped in the diagnosis and each was potentially dangerous by causing hypoglycaemia despite a concurrent glucose infusion.

Initial treatment. The immediate priority is to increase blood glucose concentrations to prevent convulsions and brain damage. Glucose infusions alone even at high rates were insufficient to restore normoglycaemia in our infants and the addition of hydrocortisone did not improve blood glucose levels. Regular, or short-acting, glucagon had only a transient effect but was useful in an emergency to cover, for example, the time that glucose infusions were being resited. Zinc protamine glucagon was used with only transient success.

Of the $\mathbf{4}$ hormones present in the normal Islet of Langerhans, only somatostatin has an inhibitory effect on insulin release. ${ }^{50}$ The hormone inhibited insulin secretion in non-malignant insulinomas in adults $^{50}$ and in an infant with nesidioblastosis. ${ }^{49}$ Since somatostatin 'deficiency' is a feature of nesidioblastosis, ${ }^{12}$ the administration of the hormone is theoretically a logical form of treatment, particularly since it inhibits glucose-stimulated insulin 
release. ${ }^{51}$ Thus concurrent administration of somatostatin should abolish the insulin-stimulating effect of the glucose needed to correct hypoglycaemia. However, this treatment can only be temporary since somatostatin inhibits several other endocrine systems and the long-term effects of prolonged treatment are unknown.

The hyperglycaemic effect of adrenaline is due, in part, to a direct inhibitory effect on the B-cell..$^{52} 53$ Cornblath and Schwartz ${ }^{30}$ recommended long-acting adrenaline (Susphrine) in the initial diagnostictherapeutic evaluation of severe neonatal hypoglycaemia, but this preparation is not available in the UK. Administration of propranolol, as used in adults with insulinomas, ${ }^{25}$ was without effect.

Diazoxide causes hyperglycaemia through inhibiting insulin release, through stimulating catecholamine secretion and mobilising glycogen. ${ }^{54}$ There are few reports of the efficacy of diazoxide in neonatal nesidioblastosis. ${ }^{1}$ In general, there has been only a poor response, with at best a transient improvement even with doses of $20 \mathrm{mg} / \mathrm{kg}$ per day or more. Baker and Stanley ${ }^{29}$ stressed that only 2 of 9 infants with onset of hyperinsulinaemic hypoglycaemia during the first month of life responded to diazoxide, whereas it was effective in 14 of 16 infants presenting after the first month and during the first year. In some cases of infantile hyperinsulinism, diazoxide exacerbates hypoglycaemia. ${ }^{55-58}$ Nevertheless, from our experience some infants with nesidioblastosis may respond well initially; it is not clear why this improvement was not maintained.

The hyperglycaemic effect of diazoxide is enhanced in vitro, and in experimental animals in vivo, by concurrent adminstration of thiazide diuretics. ${ }^{59}$ No beneficial effect was seen in these infants after the addition of chlorothiazide. Chlorpromazine also enhances diazoxide-induced hyperglycaemia ${ }^{60}$ but this combination of drugs was not tried. Phenytoin has a direct inhibitory effect on insulin secretion, and has been used in adults with insulinomas. ${ }^{23} 24$ No beneficial effect was observed when this drug was used in Case 1.

Streptozotocin is a drug which selectively destroys insulin-secreting cells, and has been used for the experimental induction of diabetes mellitus in animals, and for amelioration of hyperinsulinism in adults with malignant insulinomas. ${ }^{61}$ However, it is highly toxic, and this precludes its use in newborn infants.

An increase in blood ketone bodies occurs normally in starvation and in hypoglycaemic conditions not caused by hyperinsulinism. The increase in blood ketone bodies provides an alternative fuel for cerebral metabolism to glucose ${ }^{62}$ and may protect the brain against hypoglycaemia. Attempts were made in Case 1 to increase blood ketone body concentrations by use of a diet rich in medium chain triglycerides ${ }^{26}$ and by administration of growth hormone. ${ }^{27}$ No improvement in blood glucose or ketone body concentrations was seen during either treatment. However, on stopping the growth hormone the child immediately had a severe hypoglycaemic convulsion.

Role of surgery. We suggest that surgical treatment of hyperinsulinism is indicated early in the neonatal period provided the biochemical criteria for the diagnosis have been met (Table 8) and provided the infant remains glucose drip-dependent at infusion rates $>10-15 \mathrm{mg} / \mathrm{kg}$ per minute, despite diazoxide (20-25 mg/kg per day) and chlorothiazide. The biochemical data do not show whether the hyperinsulinism is due to a discrete adenoma or to a more diffuse form of nesidioblastosis. Resection of the former may be curative. ${ }^{28}$ When a localised lesion cannot be found, a tissue diagnosis can be established in the resected pancreas by using insulin-specific immunohistochemical methods.

The practical dilemma facing the surgeon is the extent to which the pancreas should be resected. Previous case reports suggest that the younger the age of onset the more likely that diffuse nesidioblastosis affecting the whole pancreas is the underlying disease. Nesidioblastosis cannot be diagnosed in frozen sections of the pancreas. In the absence of a detectable adenoma, a subtotal resection (80-85\%) should be performed. This may be curative ${ }^{63}$ or may lead to better control with diazoxide. ${ }^{28}$ Some infants, such as those reported here, remain hypoglycaemic despite treatment, and further resection is necessary. Case 1 undoubtedly had one more operation than was necessary. The second operation to convert the $80 \%$ resection to $95 \%$ was attempted so that some exocrine and endocrine function might be preserved. It failed partly because of the remarkable degree of subsequent compensatory hypertrophy of even this remnant. Thus we suggest that total pancreatectomy is indicated as a second procedure within 2 or 3 weeks of the first if hypoglycaemia still persists despite treatment.

A different, and technically more difficult, change was found in the pancreatic remnant of Case 3. This had the appearance of subacute pancreatitis, which made 'conservative' total pancreatectomy impossible and the common bile duct had to be excised during the removal. There have been no complications yet from the biliary diversion procedure which was necessary, but late cholangitis remains a risk. 
The complete clearance of pancreatic tissue from the common bile duct during total pancreatectomy is likely to impair its blood supply and may cause subsequent ischaemic stricture. Similarly, the destruction of the pancreaticoduodenal arteries which supply the duodenal loop may predispose to perforation, and an omental wrap to provide a source for revasculatisation and to seal perforations is an important safeguard. The preservation of the spleen is of major importance in view of the increased risk of infection after splenectomy. It should be straightforward to dissect the pancreas from the splenic artery but if this vessel has to be ligated the short gastric arteries will maintain splenic viability if the gastroepiploic arterial arcade is intact.

The need for surgery is difficult to define in the infant who appears to respond well to diazoxide. Case 2 illustrates the difficultics in managing an infant who appeared to be well controlled with blood glucose values consistently above $2 \mathrm{mmol} / 1$ with normal frequency of feeding, but who had episodes of severe hypoglycaemia for no apparent reason. This infant suffered hypoglycaemic convulsions during these periods despite close supervision in hospital. It was felt eventually that perseverance would impose an intolerable strain on the parents and expose the child to serious risk of brain damage. Subtotal pancreatectomy however, did not improve blood glucose homeostasis, and in fact the infant became glucose drip-dependent again until a total pancreatectomy was performed.

\section{Management of diabetes after total pancreatectomy.}

\section{Immediate postoperative management}

Pancreatectomy for nesidioblastosis represents an acute change from hyperinsulinism to diabetes. The operation must be covered by a secure intravenous line to supply glucose, and, postoperatively, to supply water, sodium, potassium, and glucose to match an intravenous infusion of insulin. All 3 infants required insulin within 3 hours of the final stage of the operation, when blood glucose levels were already raised and the danger of a glucoseinduced diuresis presented itself. During the first 48 hours after operation, an insulin infusion (Actrapid*) was run at about $0 \cdot 1$ units $/ \mathrm{kg}$ per hour. Monocomponent insulin was used from the outset to reduce insulin antibody formation.

Enteral feeding was soon begun with milk formula, starting with hourly feeds and gradually progressing to 2-hourly and 3-hourly feeds throughout the 24 hours. Pancrex powder was mixed with each feed

*Novo. starting at a dose of $50 \mathrm{mg}$ of powder to each $100 \mathrm{ml}$ of formula.

Once enteral feeding was established safely the transition was made to intermittent subcutaneous injections of Actrapid insulin, the dose being about 0.25 units $/ \mathrm{kg}, 6$ hourly. This dose was modified in response to measurements of blood glucose. When a reasonably stable state was achieved, generally 3 to 4 days after the initiation of enteral feeding, a transition was made to the long-term management regimen.

\section{Long-term management}

Insulin. Case 1 was started on twice-daily subcutaneous Actrapid insulin. At age 10 months this was changed to once daily Monotard* insulin which was continued until age 2 years when a small dose of Actrapid insulin was combined as a single morning injection. This remains the current insulin regimen for this child.

Cases 2 and 3 were started on Monocomponent Ultralente* insulin since feeds taken at regular intervals throughout the $\mathbf{2 4}$ hours for several months theoretically would match the very long-acting Ultralente insulin more appropriately than intermittent doses of short-acting insulin. In Case 2 Ultralente was given as a single injection before the first feed of the day at about 0600 hours. After several months the blood glucose levels were noted to be high in the first few hours after the injection, with rather lower levels 16-24 hours later. Because of this, Ultralente was begun at 2200 hours before the last feed of the day in Case 3. In this way the time of greatest danger of hypoglycaemia was diverted to the afternoon and evening hours when it might be detected and dealt with more easily. In both Cases 2 and 3 the use of Ultralente was remarkably effective and trouble free. At age 1 year both of these children were changed to Leo Retard $\dagger$ insulin given before the first feed of the day at 0700 hours. The reason for this change was the wish to abandon the middle of the night feeds and to move to a shorter acting insulin. The overall dose of insulin the 3 children have required has been about 1 unit/kg body weight per 24 hours.

Feeds. Normal volumes of infant milk formula were given to the infants initially with the introduction of non-milk foods after age 3 months. Six feeds within the 24 hours were continued up to age 10-12 months. The dose of Pancrex was initially $50 \mathrm{mg}$ with each $100 \mathrm{ml}$ of milk, but by age 1 year it had increased to $300 \mathrm{mg}$ with the milk and $600 \mathrm{mg}$ with the meals. The dose was adjusted according to the growth of the

*Novo, †Nordisk. 
children and the macroscopical appearance of their stools. Currently all $\mathbf{3}$ children are feeding well and growing normally.

Neurological development. Hyperinsulinaemic hypoglycaemia during the first year of life is a potent cause of severe brain damage and mental retardation if it is not recognised and effectively treated. ${ }^{1}$ Despite recurrent hypoglycaemia, sometimes associated with convulsions, these 3 infants, now aged $4,2 \frac{1}{2}$, and 2 years, appear to be developing normally. Regular assessment has shown that all 3 perform appropriately for their ages. Formal IQ tests have not been performed. Cases 1 and 3 have suffered febrile convulsions not associated with hypoglycaemia. The apparent satisfactory outcome of these infants may be due to the fact that although all three suffered recurrent hypoglycaemic convulsions, in no case were the symptoms allowed to persist for more than a few minutes, being terminated by glucose or glucagon.

We thank the nursing staff of the special care baby unit and paediatric intensive care unit for skilled management of the infants, Professor J P M Tizard for advice and encouragement, Professor $R$ Gitzelmann, Children's Hospital, Zurich, for measuring hepatic enzyme activities, and Mrs P Jenkins and Miss $\mathbf{S}$ Boyes for assay of intermediary metabolites.

Human growth hormone was provided by the Medical Research Council.

J $\mathbf{M} \mathbf{P}$ and $\mathbf{S} \mathbf{R} \mathbf{B}$ were supported by the Birthright Appeal, and A A-G by the National Health Service Locally Organised Research Fund.

\section{References}

1 Aynsley-Green A. Nesidioblastosis of the pancreas in infancy. In: Randle P J, Steiner D F, Whelan W J, eds. Carbohydrate metabolism and its disorders. London: Academic Press, 1981: in press.

2 Aynsley-Green A, Polak J M, Keeling J, Gough M H, Baum J D. Averted sudden neonatal death due to pancreatic nesidioblastosis. Lancet 1978; i: 550-1.

3 Stein M W. D-glucose determination with hexokinase and glucose-6-phosphate dehydrogenase. In: Bergmeyer H U, ed. Methods of enzymatic analysis. New York: Academic Press, 1963: 117.

4 Hohorst H J, Kreutz F H, Bücher T. Uber Metabolitgehalte und Metabolit-Konzentrationen in der Leber der Ratte. Biochemische $Z 1959$; 332: $18-46$.

5 Williamson D H, Mellanby J, Krebs H A. Enzymic determination of $D(-)$ - $\beta$-hydroxybutyric acid and acetoacetic acid in blood. Biochem $J$ 1962; 82: 90-6.
6 Williamson D H. L-alanine dehydrogenase. In: Bergmeyer $\mathrm{H}$ U, ed. Methods of enzymatic analysis, second edition. New York: Academic Press, 1974: 1679.

7 Albano J D M, Ekins R P, Maritz G, Turner R C. A sensitive, precise, radioimmunoassay of serum insulin relying on charcoal separation of bound and free hormone moieties. Acta Endocrinol (Kbh) 1972 ; 70: 487-509.

8 Bloom S R. Hormones of the gastrointestinal tract. $\mathrm{Br}$ Med Bull 1974; 30: 62-7.

${ }^{9}$ Pearse A G E, Polak J M. Bifunctional reagents as vapour- and liquid-phase fixatives for immunohistochemistry. Histochem J 1975; 7: 179-86.

10 Polak J M, Bloom S R. Peptidergic innervation of the gastrointestinal tract. Invest Cell Pathol 1978; 1: 1-25.

11 Hobbs S E, Polak J M. Quantitative immunocytochemistry. In: Bloom S R, ed. Gut hormones. Edinburgh: Churchill Livingstone, 1977: 87-91.

12 Polak J M, Bloom S R. Somatostatin deficiency in persistent neonatal hyperinsulinaemic hypoglycaemia. In : Marks V, Andreani D, eds. Current views on hypoglycemia and glucogen. London: Academic Press, 1980: 367-78.

13 Bussolati G, Bassa T. Thiosulfation aldehyde fuchsin (TAF) procedure for the staining of pancreatic B cells. Stain Technology 1974; 49: 313-5.

14 Hers H G. Glycogen storage diseases. In: Levine R, Luft R, eds. Advances in metabolic disorders. Vol. 1. London: Academic Press, 1964: 2-44.

15 Lowry O H, Rosebrough N J, Farr A L, Randall R J. Protein measurement with the folin phenol reagent. J Biol Chem 1951; 193: 265-75.

16 Thomas J A, Schlender K K, Larner J. A rapid filter paper assay for UDP glucose-glycogen glucosyltransferase, including an improved biosynthesis of UDP-14 Cglucose. Anal Biochem 1968; 25: 486-99.

17 Krisman C R. A method for the colorimetric estimation of glycogen with iodine. Anal Biochem 1962; 4: 17-23.

18 Coll-Garcia E, Gill J R. Insulin release by isolated pancreatic islets of the mouse incubated in vitro. Diabetologia 1969 ; 5: 61-6.

19 Ashcroft S J H, Crossley J R. The effects of glucose, $\mathrm{N}$-acetylglucosamine, glyceraldehyde, and other sugars on insulin release in vivo. Diabetologia 1975; 11 : 279-84.

20 Ashcroft S J H, Weerasinghe L C C, Randle P J. Interrelationship of islet metabolism, adenosine triphosphate content, and insular release. Biochem J 1973; 132: 223-31.

21 Ashcroft S J H, Crossley J R, Crossley P C. The effect of $\mathrm{N}$-acetylglucosamines on the biosynthesis and secretion of insulin in the rat. Biochem $J$ 1976; 154: 701-7.

22 Aynsley-Green A, Bloom S R, Williamson D H, Turner $R$ C. Endocrine and metabolic response in the human newborn to first feed of breast milk. Arch Dis Child 1977; 52: 291-5.

${ }^{23}$ Cohen M S, Bower R H, Fidler S M, Johnsonbaugh R E, Sode J. Letter: Inhibition of insulin release by diphenylhydantoin and diazoxide in a patient with benign insulinoma. Lancet 1973; i: 40-1.

24 Brodows R G, Campbell R G. Control of refractory fasting hypoglycemia in a patient with suspected insulinoma with diphenylhydantoin. J Clin Endocrinol Metab 1974 ; 38: 159-61.

25 Blum I, Doron M, Laron Z, Atsmon A. Prevention of hypoglycemic attacks by propranolol in a patient suffering from insulinoma. Diabetes $1975 ; 24$ : 535-7.

${ }^{26}$ Huttenlocher P R. Ketonemia and seizures: metabolic and anticonvulsant effects of two ketogenic diets in childhood epilepsy. Pediatr Res 1976; 10: 536-40. 
27 Ernesti M, Mitchell M L, Raben M S, Gilboa Y. Control of hypoglycaemia with diazoxide and human growth hormone. Lancet $1965 ;$ i: $628-30$.

28 Zuppinger K A. Hypoglycaemia in childhood. Monogr Paediatr 1975; 4: 23-52.

29 Baker L, Stanley C A. Hyperinsulinism in infancy: a patho-physiologic approach to diagnosis and treatment. In: Chimmello G, Laron $\mathrm{Z}$, eds. Recent progress in pediatric endocrinology. London: Academic Press, 1977: 89-100.

30 Cornblath M, Schwartz R. Disorders of carbohydrate metabolism in infancy, second edition. Vol. 3 in Major Problems in Clinical Pediatrics Series. Philadelphia: Saunders, 1976: 180-6.

31 Laidlaw G F. Nesidioblastoma, the islet tumor of the pancreas. Am J Pathol 1938; 14: 125-34.

32 Brown R E, Young R B. A possible role for the exocrine pancreas in the pathogenesis of neonatal leucine-sensitive hypoglycemia. Am J Dig Dis 1970; 15: 65-72.

33 Yakovac W C, Baker L, Hummeler K. Beta cell nesidioblastosis in idiopathic hypoglycemia of infancy. $J$ Pediatr 1971; 79: 226-31.

34 Heitz P U, Klöppel G, Häcki W H, Polak J M, Pearse A G. Nesidioblastosis: the pathologic basis of persistent hyperinsulinemic hypoglycemia in infants. Diabetes 1977 ; 26: 632-42.

35 Ashcroft S J H, Nino S. Effects of phloretin and dextranlinked phloretin on pancreatic islet metabolism and insulin release. Biochim Biophys Acta 1978; 538: 334-42.

36 Ashcroft $\mathbf{S ~ J ~ H . ~ T h e ~ c o n t r o l ~ o f ~ i n s u l a r ~ r e l e a s e ~ b y ~ s u g a r s . ~}$ Ciba Found Symp 1976; New series 41 : 117-39.

37 Ashcroft S J H, Bunce J, Lowry M, Hansen S E, Hedeskov C J. The effect of sugar on (pro)insulin biosynthesis. Biochem J 1978; 174: 517-26.

38 Andersson A, Borg H, Groth C-G, et al. Survival of isolated human islets of Langerhans maintained in tissue culture. J Clin Invest 1976; 57: 1295-301.

39 Misugi K, Misugi N, Sotos J, Smith B. The pancreatic islet of infants with severe hypoglycemia. Arch Pathol 1970; 89: 208-20.

40 Woo D, Scopes J W, Polak J M. Idiopathic hypoglycaemia in sibs with morphological evidence of nesidioblastosis of the pancreas. Arch Dis Child 1976; 51: 528-31.

41 Sovik O, Fevang F O, Finne P H. Familial nesidioblastosis. In proceedings of the European Society for Paediatric Research, Turku, Finland, 1978. Abstract 83.

42 Vance J E, Stoll R W, Kitabchi A E, Williams R H, Wood F C, Jr. Nesidioblastosis in familial endocrine adenomatosis. JAMA 1969; 207: 1679-82.

43 Anonymous. Neonatal hypoglycaemia and nesidioblastosis. Lancet 1978; i: 193-4.

44 Polak J M, Wigglesworth J S. Letter: Islet-cell hyperplasia and sudden infant death. Lancet 1976; ii: 570-1.

${ }^{45}$ Cox J N, Guelpa G, Terrapon M. Letter: Islet-cell hyperplasia and sudden infant death. Lancet 1976; ii: 739-40.

46 Turner R C, Heding L G. Plasma proinsulin, C-peptide, and insulin in diagnostic suppression tests for insulinomas. Diabetologia 1977; 13: 571-7.

47 Bier D M, Leake R D, Haymond M W, et al. Measurement of true glucose production rates in infancy and childhood with 6.6-dideuteroglucose. Diabetes 1977 ; 26: 1016-23.

48 Stanley C A, Baker L. Hyperinsulinism in infancy: diagnosis by demonstration of abnormal response to fasting hypoglycemia. Pediatrics 1976; 57: 702-11.

49 Hirsch H J, Loo S, Evans N, Crigler J F, Jr, Filler R M, Gabbay K H. Hypoglycemia of infancy and nesidioblastosis, studies with somatostatin. $N$ Engl J Med 1977; 296: 1323-6.

50 Alberti K G M M, Christensen N J, Christensen S E, et al. Inhibition of insulin secretion by somatostatin. Lancet 1973; ii: 1299-301.

51 Christensen S E, Hansen Aa P, Lundbaek K, Ørskov H, Seyer-Hansen K. Letter: Somatoștatin and insulinoma. Lancet 1975 ; i: 1426.

52 Coore H G, Randle P J. Regulation of insulin secretion studied with pieces of rabbit pancreas incubated in vitro. Biochem J 1964; 93: 66-78.

53 Porte D, Jr, Graber A L, Kuzuya T, Williams R H. The effect of epinephrine on immunoreactive insulin levels in man. J Clin Invest 1966; 45: 228-36.

54 Smith H M, ed. Diazoxide and the treatment of hypoglycemia. Ann NY Acad Sci 1968; 150: 191-467.

55 Garces I Y, Drash A, Kenny F M. Islet cell tumor in the neonate. Pediatrics 1968; 41 : 789-96.

56 Salinas E D, Jr, Mangurten H H, Roberts S S, Simon W $H$, Cornblath $M$. Functioning islet cell adenoma in the newborn. Report of a case with failure of diazoxide. Pediatrics 1968; 41: 646-53.

${ }^{57}$ Grant D B, Barber P R H. Islet cell tumour causing hypoglycaemia in a newborn infant. Arch Dis Child 1970; 45: 434-6.

58 Buist N R M, Campbell J R, Castro A, Brant B. Congenital islet cell adenoma causing hypoglycemia in a newborn. Pediatrics 1971; 47: 605-9.

59 Peters G, Roch-Ramel F. Thiazide diuretics and related drugs. In: Handbook of experimental pharmacology. Vol. 24. Berlin: Springer-Verlag, 1969: 257-385.

60 Aynsley-Green A, Illig R. Letter: Enhancement by chlorpromazine of hyperglycaemic action of diazoxide. Lancet 1975; ii: 658-9.

61 Broder L E, Carter S K. Pancreatic islet cell carcinoma. II. Results of therapy with streptozotocin in 52 patients. Ann Intern Med 1973; 79: 108-18.

${ }_{62}$ Page M A, Williamson D H. Enzymes of ketone body utilisation in human brain. Lancet 1971; ii: 66-8.

${ }^{63}$ Crowder W L, Maclaren N K, Gutberlet R L, Frost J L, Mason G R, Cornblath M. Neonatal pancreatic B-cell hyperplasia. Report of a case with failure of diazoxide and benefit of early subtotal pancreatectomy. Pediatrics 1976; 57: 897-900.

64 Ashcroft S J H, Bassett J M, Randle P J. Isolation of human pancreatic islets capable of releasing insulin and metabolising glucose in vitro. Lancet 1971 ; i: 888-9.

Correspondence to Dr A Aynsley-Green, Department of Paediatrics, John Radcliffe Hospital, Headington, Oxford OX3 9DU.

Received 12 May 1980 